Egyptian Journal of Aquatic Biology \& Fisheries

Zoology Department, Faculty of Science,

Ain Shams University, Cairo, Egypt.

ISSN $1110-6131$

Vol. 24(6): 281 - 294 (2020)

www.ejabf.journals.ekb.eg

\title{
Analysis of morphometric and meristic characteristics of Pomadasys stridens (Forsskål, 1775), Family: Haemulidae from the Gulf of Suez, Red Sea, Egypt.
}

\author{
Aya A. A. Basuonie ${ }^{1}$, Manal M. Sabrah ${ }^{2}$, Asaar S. H. El-Sherbeny ${ }^{2 *}$ and \\ Mohamed S. A. El-Sabbagh ${ }^{3}$
}

1. General Authority for Fish Resources Development (GAFRD), Suez. Egypt.

${ }^{2}$. National Institute of Oceanography and Fisheries, Fisheries Division, Suez, Egypt.

${ }^{3}$. Suez University, Faculty of Fish Resources, Human Development and Economic Dept., Egypt.

* Corresponding Author: Asar_Elsherbeny@yahoo.com

\section{ARTICLE INFO}

Article History:

Received: Aug. 28, 2020

Accepted: Sept. 9, 2020

Online: Sept. 12, 2020

Keywords:

Haemulidae;

Pomadasys stridens;

Suez Gulf;

morphology;

morphometrics;

meristics.

\begin{abstract}
The morphological diagnosis, morphometric, and meristic characters for the striped piggy Pomadasys stridens in the Gulf of Suez were studied by the examination of 165 specimens collected during the fishing season 2017/2018. These fishes ranged from 8.2 to $16.3 \mathrm{~cm}$ in total length and 7.3 to $57.3 \mathrm{~g}$ in weight. Twenty morphometric and eleven meristic characters were investigated in detail. The analysis of morphometric characters revealed that the morphometric measurements of various body parts were dependent on body size and there is a gradual increase in morphometric measurements with an increase in body length. Regression analyses were performed between the independent variable "TL" and the dependent variables "FL, SL, HL, HD, , BD, PreDL, DFL, PrePL, PFL, PreVL, VFL, PreAL, AFL, CFL, CFH, CPL, CPD” as well as between the independent variable "HL" and the dependent variables "ED, PreOL". The results showed that there was a positive linear relationship between various morphometric measurements and TL as well as HL with a medium to a high degree of correlation. On the other hand, the fish showed constant meristic characters, where there was no change in meristic counts with the increase in body length. The fin formula can be written as D XII+14; A III+8; P 15; V I+5; C 15 and the recorded number of LLS, GR, and $\mathrm{V}$ were 57,22 , and 24 respectively.
\end{abstract}

\section{INTRODUCTION}

Morphological characteristics are of fundamental importance in fishery biology, where it is the major source of information for taxonomic and evolutionary studies. Taxonomic identification is the initial step in the study of a species. For estimating the similarities and dissimilarities among the taxonomic categories, many workers had used protein studies and DNA sequences, but this is practically not easy especially due to the expenses. The description of morphological characters are considered the easiest and authentic method of fish identification which is termed as morphological systematic. These characters are most generally divided into two major categories; the morphometric 
and meristic characters. The morphometric measurements, meristic counts, shape and size provide data useful for taxonomic status which is considered the first line of approach when investigating the stock structure of a fish species (Brraich and Akhter, 2015; Ukenyea et al., 2019).

Family Haemulidae (Perciformes), commonly called grunts, are small to mediumsized fishes, widely inhabiting shallow coastal waters in tropical and subtropical regions of the world. It comprises two subfamilies; Haemulinae and Plectorhinchinae, and includes about 134 species in 19 genera distributed widely in the world (Nelson, 1994; Froese and Pauly, 2020).

Haemulid species are morphologically diversified fishes with wondrous and changeable coloration; head and body usually silvery, grey, and light or reddish brown, frequently mottled, spotted or stripped with dusky, blue, red or yellow. They are typical perch-like fishes, have oblong and moderately compressed body, head profile strongly convex, and covered with small or moderate ctenoid scales, present on entire head except tip of snout, lips, and chin. Mouth small or moderate, chin with two pores anteriorly and a median pit or six pores and no pit. They are characterized by having single dorsal fin with 9 to 15 strong spines and 12 to 26 sort rays; pectoral fins long, 1st ray sometimes forming a short filament; pelvic fins below base of pectoral fins, with 1 spine and 5 soft rays; anal fin with 3 spines, the second often very strong, and 7 to 9 soft rays; caudal fin truncate or emarginate and rounded in juveniles (Fischer and Bianchi, 1984; Burhanuddin and Iwatsuki, 2012; Liang et al., 2012; Fricke et al., 2020; Froese and Pauly, 2020).

Haemulids are one of the most ecologically and commercially important groups of nearshore fishes. This family have a synonym Pomadasyidae due to having nearly 35 species of the genus Pomadasys Lacépède, 1802 (Fischer and Bianchi, 1984; Al-Faisal and Mutlak, 2018). Pomadasys stridens Forsskål, 1775 (stripped piggy), one of the most common and most important species in the Gulf of Suez. It is exploited by trawl net and contributes about $3 \%$ of the total Gulf of Suez catch (GAFRD, 2018). Several studies have been carried out on P. stridens in the Gulf of Suez and Suez Canal, Egypt by covering its abundance, food and feeding, reproductive biology, stock assessment, and impacts of water quality on its yield (Yousif, 1990; Yousif, 2004; El-Ganainy and Sabra, 2008; El-Azim et al., 2017; Osman et al., 2019). To the best of our knowledge, no previous studies had investigated the morphometric and meristic characterization of $P$. stridens in these areas, so the present study aims to give information about the morphometric and meristic characteristics of $P$. stridens in the Gulf of Suez, Red Sea, Egypt.

\section{MATERIALS AND METHODS}

\section{Study Area:}

Gulf of Suez (Fig. 1) "Latitude: $29^{\circ} 58^{\prime} 25.36 "$ N; Longitude: $32^{\circ} 31^{\prime} 34.57^{\prime \prime}$ E” is the northwestern arm of the Red Sea, east of the Sinai Peninsula of Egypt. It is linked to the Mediterranean Sea by the Suez Canal and it is an important shipping route. The length of the gulf from its mouth at the Strait of Jubal to its head at the city of Suez 314 $\mathrm{km}$, and it varies in width from 19 to $32 \mathrm{~km}$. with an average depth of $40 \mathrm{~m}$. and maximum depth 70. There are four fishing harbors along the Gulf of Suez; Salakhana, Ataka, Ras Gharib and El-Tor, while the Ataka fishing harbor is considered the largest one and have the largest numbers of fishing vessels operated at the Suez Gulf. 


\section{Sampling:}

Samples of the stripped piggy Pomadasys stridens (Fig. 2) were collected from the commercial landings of trawlers at Ataka fishing harbor at Suez city during the fishing season 2017/2018, and transported to the laboratory for the morphometric and meristic investigations.

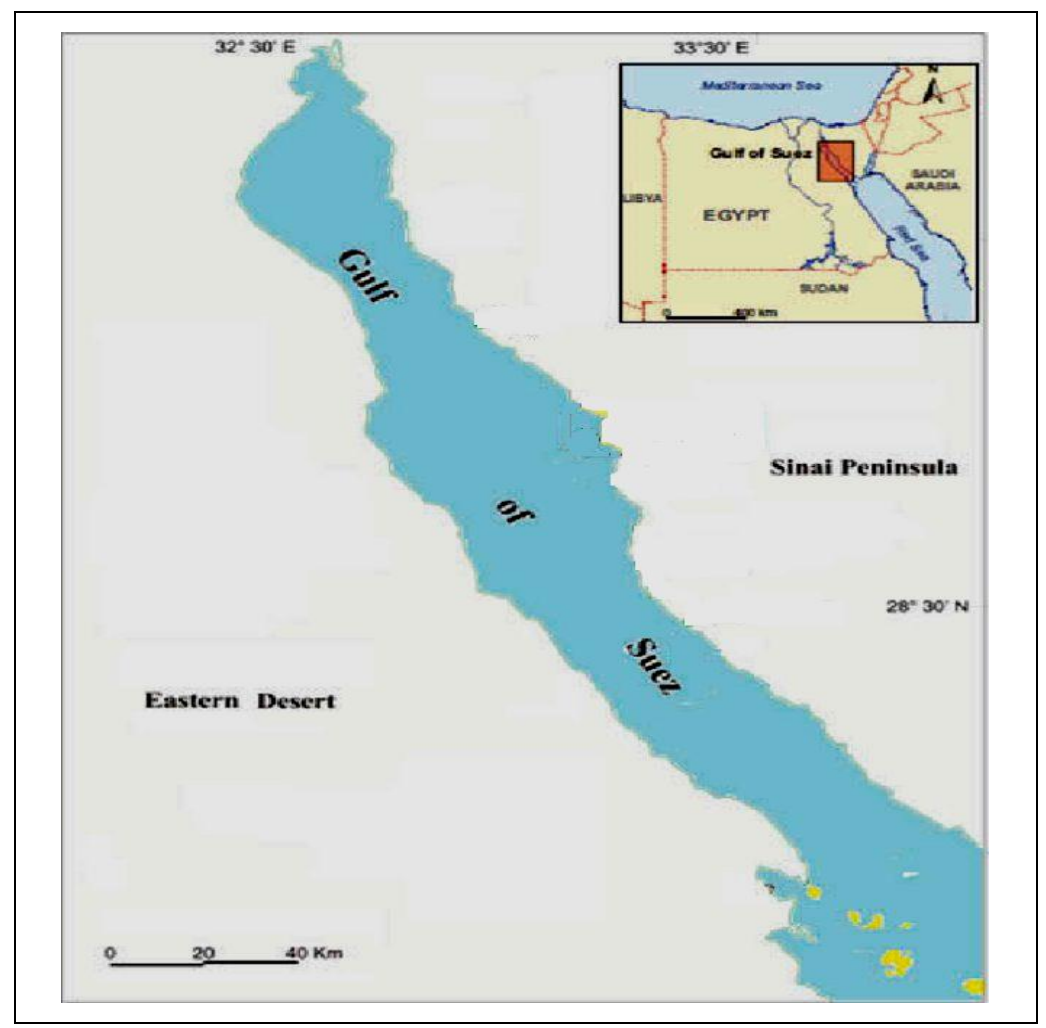

Fig. (1): A map for the study area; Gulf of Suez.

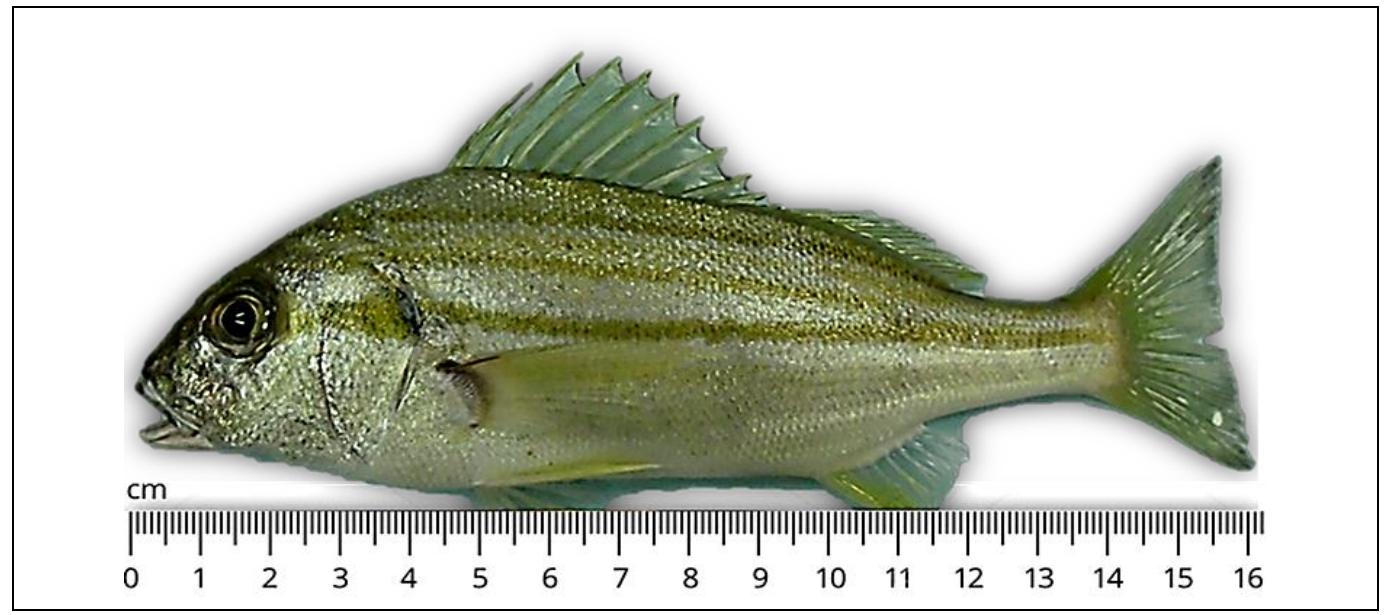

Fig. (2): Pomadasys stridens from the Gulf of Suez. 


\section{Morphometrics and Meristics Parameters:}

A total of 165 specimens of $P$. stridens ranging in size from $8.2 \mathrm{~cm}$ to $16.3 \mathrm{~cm}$ in total length (TL) and 7.3 to $57.3 \mathrm{~g}$ in weight (W) were used for morphometric measurements and meristic counts. Measuring board and tape measure, having graduations in millimeter were used for various measurements. All morphometric measurements and meristic counts were based on the standard procedures described by Appa Rao (1966) as well as Dwivedi and Menezes (1974).

The investigated specimens were divided into three length groups; group I (8 $10.9 \mathrm{~cm} ; 55$ specimen), group II $(11-13.9 \mathrm{~cm} ; 55$ specimen) and group III (14 - 16.9 $\mathrm{cm} ; 55$ specimen). Twenty morphometric characters and eleven meristic characters (Fig. 3 and Table 1) were obtained from each fish specimen. All the measurements of different morphometric characters were determined as percentage of TL; except ED and PreOL are recorded in \% of HL.

The morphometric data were subjected to regression analysis in order to get the relationship between each morphometric character and total length except for eye diameter and preorbital length were studied in relation to head length.

Table (1): The morphometric and meristic characters investigated in $P$. stridens from the Gulf of Suez.

\begin{tabular}{|r|l|l|r|l|l|}
\hline \multicolumn{2}{|c|}{ 20 Morphometric characters } & \multicolumn{3}{c|}{ Character } & Acronym \\
\hline \multicolumn{2}{|c|}{ Character } & Acronym & \multicolumn{3}{|c|}{ Meristic characters } \\
\hline $\mathbf{1}$ & Total length & TL & $\mathbf{1}$ & Dorsal fin spines & DFS \\
\hline $\mathbf{2}$ & Fork length & FL & D & Dorsal fin rays & DFR \\
\hline $\mathbf{3}$ & Standard length & SL & $\mathbf{3}$ & Anal fin spines & AFS \\
$\mathbf{4}$ & Head length & HL & $\mathbf{4}$ & Anal fin rays & AFR \\
\hline $\mathbf{5}$ & Head depth & HD & $\mathbf{5}$ & Pectoral fin rays & PFR \\
\hline $\mathbf{6}$ & Eye diameter & ED & $\mathbf{6}$ & Pelvic fin spines & VFS \\
$\mathbf{7}$ & Pre orbital length & PreOL & $\mathbf{7}$ & Pelvic fin rays & VFR \\
$\mathbf{8}$ & Body depth & BD & $\mathbf{8}$ & Caudal fin rays & CFR \\
\hline $\mathbf{9}$ & Pre dorsal length & PreDL & $\mathbf{9}$ & Lateral line scales & LLS \\
\hline $\mathbf{1 0}$ & Dorsal fin length & DFL & $\mathbf{1 0}$ & Gill rakers & GR \\
\hline $\mathbf{1 1}$ & Pre pectoral length & PrePL & $\mathbf{1 1}$ & Vertebrae & V \\
\hline $\mathbf{1 2}$ & Pectoral fin length & PFL & & & \\
$\mathbf{1 3}$ & Pre pelvic length & PreVL & & & \\
\hline $\mathbf{1 4}$ & Pelvic fin length & VFL & & & \\
\hline $\mathbf{1 5}$ & Pre anal length & PreAL & & & \\
\hline $\mathbf{1 6}$ & Anal fin length & AFL & & & \\
\hline $\mathbf{1 7}$ & Caudal fin length & CFL & & & \\
\hline $\mathbf{1 8}$ & Caudal fin height & CFH & & & \\
\hline $\mathbf{1 9}$ & Caudal peduncle length & CPL & & & \\
\hline $\mathbf{2 0}$ & Caudal peduncle depth & CPD & & & \\
\hline
\end{tabular}




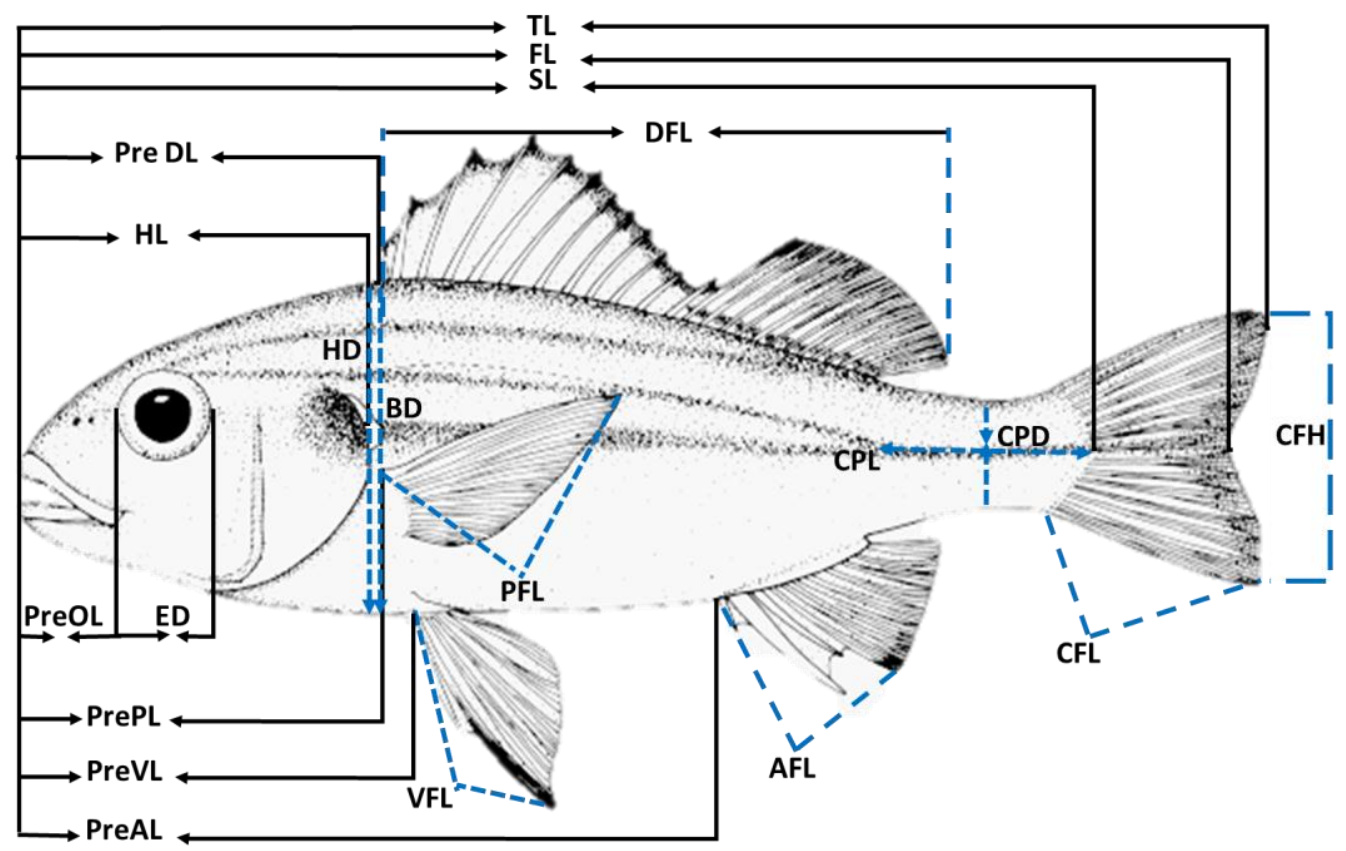

Fig. (3): The morphometric measurements investigated in $P$. stridens from Suez Gulf (TL - Total length; FL - Fork length; SL - Standard length; HL - Head length; HD - Head depth; ED - Eye Diameter; PreOL - Pre orbital length; BD - Body depth; PreDL - Pre dorsal length; DFL - Dorsal fin length; PrePL - Pre pectoral length; PFL - Pectoral fin length; PreVL - Pre pelvic length; VFL - Pelvic fin length; PreAL - Pre anal length; AFL - Anal fin length; CFL - Caudal fin length; CFH Caudal fin height; CPL - Caudal peduncle length; CPD - Caudal peduncle depth).

\section{RESULTS AND DISCUSSION}

\section{Morphological Features:}

Investigation of morphological aspects of the striped piggy Pomadasys stridens population inhabiting the Gulf of Suez revealed that they are medium sized fishes (Max. TL $16.3 \mathrm{~cm}$ and Max. W $57.3 \mathrm{~g}$ ), having moderately compressed body form. Body yellowish silvery-grey with white belly. Body is characterized by having four goldenbrown longitudinal stripes on the upper half of the body; the most distinct one extend from a dark spot on the upper margin of operculum to the caudal peduncle, and the other three less distinct ones above it. The head is convex dorsally, with small subterminal mouth; jaw with cardiform teeth; chin with two pores anteriorly and a median pit. The body covered with small ctenoid scales, present on entire head except for snout, lips, and chin. They are characterized by having single continuous; deeply notched dorsal fin, supported by spiny and soft rays. Pelvic fin position is thoracic; at the base of pectoral fin and the caudal fin is emarginated (moderately forked). These morphological details for $P$. stridens of the present study relatively come in accordance with the descriptions of Smith and Mckay (1986); Iwatsuki et al. (1995); Bilecenoğlu et al. (2009); Safi et al. (2014); Akyol and Ünal (2016); Akyol and Çoker (2018) as well as Froese and Pauly (2020) for $P$. stridens in different regions worldwide. 


\section{Morphometric Characters:}

The morphometric measurements of various body parts were recorded for each specimen in the three length groups (I, II, III) and the mean \pm SE were presented in table (2). P. stridens fish in the Gulf of Suez grow up to $16.3 \mathrm{~cm}$ TL $(8.3-16.3 \mathrm{~cm}), 15.2 \mathrm{~cm}$ FL $(7.7-15.2 \mathrm{~cm})$ and $14 \mathrm{~cm} \mathrm{SL}(7-14 \mathrm{~cm})$ with an average $12.5,11.8$ and $10.7 \mathrm{~cm}$ for TL, FL and SL respectively. HL $(1.6-4 \mathrm{~cm})$, HD $(1.3-3.3 \mathrm{~cm})$, ED $(0.3-1.0 \mathrm{~cm})$, PreOL $(0.3-1.0 \mathrm{~cm})$, BD $(1.5-3.3 \mathrm{~cm})$, PreDL $(1.9-4.5 \mathrm{~cm})$, DFL $(2.9-5.6 \mathrm{~cm})$, PrePL $(1.8-4.4 \mathrm{~cm})$, PFL $(1.1-2.4 \mathrm{~cm})$, PreVL $(1.6-4.1 \mathrm{~cm})$, VFL $(0.8-1.7 \mathrm{~cm})$, PreAL (3.7 - 8.5 cm), AFL (0.5 - 1.0), CFL $(1.0-2.1 \mathrm{~cm})$, CFH $(0.2-0.8 \mathrm{~cm}), \mathrm{CPL}$ $(0.8-2.1 \mathrm{~cm})$ and CPD $(0.2-1.0 \mathrm{~cm})$, with an average 2.71, 2.21, 0.51, 0.61, 2.54, 3.19, 4.41, 3.06, 1.61, 2.86, 1.18, 6.42, 0.71, 1.70, 0.57, 1.57 and $0.68 \mathrm{~cm}$ for HL, HD, ED, PreOL, BD, PreDL, DFL, PrePL, PFL, PreVL, VFL, PreAL, AFL, CFL, CFH, CPL and $\mathrm{CPD}$ respectively.

From results (table 2), it is clear that all morphometric characters investigated in the present study; FL, SL, HL, HD, ED, PreOL, BD, PreDL, DFL, PrePL, PFL, PreVL, VFL, PreAL, AFL, CFL, CFH, CPL and CPD are increasing with increasing body size TL in the three length groups (I, II, III). It means that morphometric measurements are dependent on body size and there is a gradual change in morphometric characters with increase in body length. In other words all the morphometric parameters grow symmetrically when observed in different length groups (I, II, III).

The previous studies of $P$. stridens worldwide did not analyze all the morphometric characters in details as in the present investigation. The results of the present study are slightly similar to that given by Smith and Mckay (1986), they found that SL: $23 \mathrm{~cm}$ with an average $10 \mathrm{~cm}$; HL: $2.8-3.4$; BD: $3.14-3.34 \mathrm{~cm}$. Bilecenoğlu et al. (2009) $(13.3-15.8 \mathrm{~cm}$ TL, $11.5-13.8 \mathrm{~cm}$ SL, head length: $3.3-3.5 \mathrm{~cm}$, body depth: $3.2-3.5$ $\mathrm{cm}$, caudal peduncle depth: $10.7-14.4$, Eye diameter: $3.5-4.3 \mathrm{~cm}$, snout length: $2.8-$ $3.3 \mathrm{~cm}$, postorbital length: $1.9-2.3 \mathrm{~cm}$, preopercular length: $1.3-1.6 \mathrm{~cm}$ ) for $P$. stridens, from the Eastern Mediterranean Sea. Bailly et al. (2010) had reported 14.3 and $11.7 \mathrm{~cm}$ for TL and SL of $P$. stridens respectively. Some morphometric measurements had been studied by Safi et al. (2014) for males and females specimens of $P$. stridens from Karachi Coast, Pakistan. Their results showed the same values in both sexes; 16.5 , $4.2,1.4,1.2,1.7 \& 16.9,4.3,1.4,1.2,1.7 \mathrm{~cm}$ for total length, head length, snout length, eye diameter and caudal peduncle in males and females respectively. Iglesias and Frotte (2015) found that TL, FL, SL were 14.9, 13.9 and $12.3 \mathrm{~cm}$ respectively for $P$. stridens in the Mediterranean Sea, Cyprus. Akyol and Ünal (2016) had reported the morphometric charcters for $P$. stridens from the Aegean Sea, Turkey and the results were 13, 12.3, 11.1, 3.5, 3.9, 3.4, 6.8, 3.3, 0.9 and $1 \mathrm{~cm}$ for TL, FL, SL, BD, PreDL, PrePL, PreAL, HL, ED and PreOL respectively. Also the morphometric measurements 13.7, 11.7, 3.3, 3.5, 3.4, 7.6, 3.2, 1.0 and $0.9 \mathrm{~cm}$ for TL, SL, BD, PreDL, PreVL, PreAL, HL, ED and PreOL respectively were documented by Akyol and Çoker (2018) for P. stridens, captured from Marmaris Bay, SE Aegean Sea, Turkey.

The percentage ratio of various morphometric measurements in relation to TL and HL for P. stridens from Gulf of Suez were given in table (3). As may be seen from the table, FL $93.8 \%$ and SL $85.6 \%$ of TL. High percentages of FL and SL in relation to TL imply a small and slightly forked caudal fin. Small head; HL $21.6 \%$ and HD $17.6 \%$ of TL. The snout length (pre orbital length) PreOL $22.3 \%$ of HL; ED $18.9 \%$ of HL. Body relatively elongate, its BD $20.3 \%$ of TL. Fin lengths constitute 35.3, 12.8, 9.4 and $5.7 \%$ 
of TL for DFL, PFL, VFL and AFL respectively. PreDL and PrePL compose a 25.5, 24.4 $\%$ of TL, indicating that the dorsal and pectoral fin originate relatively at the same line of the fish body. Also the PrePL and PreVL compose 24.4 and $24.7 \%$ of TL respectively, indicating that the pectoral fin is originated little before the pelvic fin and hence a thoracic position of the pelvic fin. PreAL compose $58.2 \%$ of TL referring to an anal fin start further away and exceed the middle of the belly. A small caudal fin; CFL and CFH equals 13.7 and $4.5 \%$ of TL respectively. A slender caudal peduncle; CPL and CPD represent 12.6 and $5.4 \%$ of TL respectively.

Table (2): The morphometric characters of $P$. stridens from Gulf of Suez.

\begin{tabular}{|c|c|c|c|c|c|}
\hline \multicolumn{2}{|c|}{ Character } & \multirow{2}{*}{$\begin{array}{c}\text { Length group } \\
\text { (I) }\end{array}$} & \multirow{2}{*}{$\begin{array}{c}\begin{array}{c}\text { Length group } \\
\text { (II) }\end{array} \\
12.6 \pm 0.07 \\
\end{array}$} & \multirow{2}{*}{$\begin{array}{c}\begin{array}{c}\text { Length group } \\
\text { (III) }\end{array} \\
14.3 \pm 0.12 \\
\end{array}$} & \multirow{2}{*}{$\begin{array}{c}\text { Mean } \\
\text { (I, II, III) } \\
12.5 \pm 0.13\end{array}$} \\
\hline$\underline{1}$ & TL & & & & \\
\hline$\underline{2}$ & FL & $10.1 \pm 0.12$ & $11.8 \pm 0.07$ & $13.4 \pm 0.11$ & $11.8 \pm 0.12$ \\
\hline$\underline{3}$ & SL & $9.2 \pm 0.12$ & $10.8 \pm 0.07$ & $12.2 \pm 0.01$ & $10.7 \pm 0.11$ \\
\hline$\underline{4}$ & HL & $2.4 \pm 0.04$ & $2.7 \pm 0.03$ & $3.0 \pm 0.05$ & $2.7 \pm 0.03$ \\
\hline 5 & HD & $1.9 \pm 0.04$ & $2.2 \pm 0.03$ & $2.5 \pm 0.04$ & $2.2 \pm 0.03$ \\
\hline$\underline{6}$ & ED & $0.5 \pm 0.01$ & $0.5 \pm 0.01$ & $0.6 \pm 0.02$ & $0.5 \pm 0.01$ \\
\hline$\overline{7}$ & PreOL & $0.5 \pm 0.01$ & $0.6 \pm 0.02$ & $0.7 \pm 0.02$ & $0.6 \pm 0.01$ \\
\hline$\underline{8}$ & BD & $2.2 \pm 0.04$ & $2.6 \pm 0.04$ & $2.8 \pm 0.04$ & $2.5 \pm 0.03$ \\
\hline$\underline{9}$ & PreDL & $2.8 \pm 0.05$ & $3.2 \pm 0.05$ & $3.6 \pm 0.07$ & $3.2 \pm 0.04$ \\
\hline 10 & DFL & $3.9 \pm 0.07$ & $4.5 \pm 0.08$ & $4.8 \pm 0.07$ & $4.4 \pm 0.05$ \\
\hline$\underline{11}$ & PrePL & $2.7 \pm 0.04$ & $3.1 \pm 0.03$ & $3.5 \pm 0.05$ & $3.1 \pm 0.04$ \\
\hline$\overline{12}$ & PFL & $1.4 \pm 0.03$ & $1.6 \pm 0.05$ & $1.9 \pm 0.05$ & $1.6 \pm 0.03$ \\
\hline$\underline{13}$ & \begin{tabular}{|l} 
PreVL \\
\end{tabular} & $2.5 \pm 0.04$ & $2.9 \pm 0.03$ & $3.2 \pm 0.05$ & $2.9 \pm 0.04$ \\
\hline$\underline{14}$ & VFL & $1.0 \pm 0.02$ & $1.2 \pm 0.03$ & $1.3 \pm 0.03$ & $1.2 \pm 0.02$ \\
\hline$\underline{15}$ & PreAL & $5.5 \pm 0.08$ & $6.5 \pm 0.07$ & $7.3 \pm 0.09$ & $6.4 \pm 0.07$ \\
\hline$\overline{\underline{16}}$ & AFL & $0.7 \pm 0.01$ & $0.7 \pm 0.02$ & $0.8 \pm 0.01$ & $0.7 \pm 0.01$ \\
\hline 17 & CFL & $1.6 \pm 0.03$ & $1.7 \pm 0.02$ & $1.8 \pm 0.03$ & $1.7 \pm 0.02$ \\
\hline$\overline{18}$ & CFH & $0.5 \pm 0.01$ & $0.6 \pm 0.01$ & $0.7 \pm 0.01$ & $0.6 \pm 0.01$ \\
\hline 19 & CPL & $1.4 \pm 0.05$ & $1.6 \pm 0.05$ & $1.6 \pm 0.05$ & $1.6 \pm 0.03$ \\
\hline$\underline{20}$ & CPD & $0.5 \pm 0.02$ & $0.7 \pm 0.02$ & $0.7 \pm 0.02$ & $0.7 \pm 0.01$ \\
\hline & $\mathbf{N}$ & 55 & 55 & 55 & 165 \\
\hline
\end{tabular}

* Values are expressed as mean \pm SE.

So far, these findings agree with those of the previous studies. Bailly et al. (2010) had studied some morphometric measurements as well as their percentages to total and head length and the ratios were 85.3, 94.2, 56.2, 26.7, 28.4, 28.3, 25.9, 27.6 \% TL, as well as 31.3, 23.9 \% HL for SL, FL, PreAL, PreDL, PreVL, PrePL, BD, HL, ED and PreOL respectively. Some morphometric measurements had been studied and expressed as \% to total length by Safi $\boldsymbol{e t}$ al. (2014) for males and females specimens of P. stridens 
from Karachi Coast, Pakistan. Their results showed the same values in both sexes; 25.7, 8.7, 7.2, 10.5 \& 25.8, 8.5, 7.1, $10.3 \%$ TL for head length, snout length, eye diameter and caudal peduncle in males and females respectively. Akyol and Ünal (2016) had reported the morphometric charcters as well as their ratio for $P$. stridens from the Aegean Sea, Turkey and the proportions were 94.6, 85.4, 26.9, 30.0, 26.2, 52.3, 25.4, 6.9 of \% TL as well as $30.3 \%$ of HL for FL, SL, BD, PreDL, PrePL, PreAL, HL, ED and PreOL respectively. Furthermore Akyol and Çoker (2018) had documented the morphometric measurements and their ratios for $P$. stridens, captured from Marmaris Bay, SE Aegean Sea, Turkey as follow 85.4, 24.1, 25.5, 24.8, 55.5, $23.4 \%$ TL and 31.3, 28.1\% HL for SL, BD, PreDL, PreVL, PreAL, HL, ED and PreOL respectively.

Table (3): The percentage ratio of various morphometric characters in relation to TL and HL for $P$. stridens from Gulf of Suez.

\begin{tabular}{|c|c|c|}
\hline \multicolumn{2}{|c|}{ Character } & Percentages \\
\hline$\underline{1}$ & FL & $93.8 \% \mathrm{TL}$ \\
\hline$\underline{2}$ & SL & $85.6 \% \mathrm{TL}$ \\
\hline$\underline{\mathbf{3}}$ & HL & $21.6 \% \mathrm{TL}$ \\
\hline$\underline{4}$ & HD & $17.6 \% \mathrm{TL}$ \\
\hline$\underline{5}$ & ED & $18.9 \% \mathrm{HL}$ \\
\hline$\underline{6}$ & PreOL & $22.3 \% \mathrm{HL}$ \\
\hline$\underline{7}$ & BD & $20.3 \% \mathrm{TL}$ \\
\hline$\overline{\overline{8}}$ & PreDL & $25.5 \% \mathrm{TL}$ \\
\hline$\underline{\overline{9}}$ & DFL & $35.3 \% \mathrm{TL}$ \\
\hline$\underline{10}$ & PrePL & $24.4 \% \mathrm{TL}$ \\
\hline$\underline{11}$ & PFL & $12.8 \% \mathrm{TL}$ \\
\hline$\underline{12}$ & PreVL & $24.7 \% \mathrm{TL}$ \\
\hline$\underline{13}$ & VFL & $9.4 \% \mathrm{TL}$ \\
\hline$\underline{14}$ & PreAL & $58.2 \% \mathrm{TL}$ \\
\hline 15 & AFL & $5.7 \% \mathrm{TL}$ \\
\hline$\underline{16}$ & CFL & $13.7 \% \mathrm{TL}$ \\
\hline$\underline{\mathbf{1 7}}$ & CFH & $4.5 \% \mathrm{TL}$ \\
\hline$\underline{18}$ & CPL & $12.6 \% \mathrm{TL}$ \\
\hline$\underline{19}$ & CPD & $5.4 \% \mathrm{TL}$ \\
\hline
\end{tabular}

The Regression analysis were performed between the independent variable "TL" and the dependent variables "FL, SL, HL, HD, , BD, PreDL, DFL, PrePL, PFL, PreVL, VFL, PreAL, AFL, CFL, CFH, CPL, CPD" as well as between the independent variable "HL" and the dependent variables "ED, PreOL". The estimated regression equations for various morphometric characteristics as function of TL and HL were given in table (4). Also the relationship between different morphometric characters and TL were displayed in Fig. (4). It is clear that there is a positive linear relationship between FL, SL HL, HD, ED, PreOL BD, PreDL, DFL, PrePL, PFL, PreVL, VFL, PreAL, AFL, CFL, CFH, CPL, CPD 
and TL; also between ED, PreOL and HL. Moreover the calculated value of correlation coefficient " $\mathrm{R}$ " of those relationships indicate a medium to high degree of correlation between the investigated variables. Strong positive linear relationship were observed between FL/TL $(\mathrm{R}=0.984)$, SL/TL $(\mathrm{R}=0.973)$, HL/TL $(\mathrm{R}=0.838)$, HD/TL $(\mathrm{R}=$ 0.805), PreDL/TL $(\mathrm{R}=0.757)$, PrePL/TL $(\mathrm{R}=0.871)$, PreVL/TL $(\mathrm{R}=0.869)$ and PreAL/TL $(\mathrm{R}=0.902)$. This is meaning that the fish increases in FL, SL, HL, HD, PreDL, PrePL, PreVL, PreAL perfectly at the same rate with TL. The moderate positive linear relationship were observed between $\mathrm{BD} / \mathrm{TL}(\mathrm{R}=0.736), \mathrm{ED} / \mathrm{HL}(\mathrm{R}=0.506)$, PreOL/HL $(\mathrm{R}=0.653), \mathrm{DFL} / \mathrm{TL}(\mathrm{R}=0.614), \mathrm{PFL} / \mathrm{TL}(\mathrm{R}=0.642), \mathrm{VFL} / \mathrm{TL}(\mathrm{R}=0.598)$, AFL/TL (0.387), CFL/TL $(\mathrm{R}=0.647), \mathrm{CFH} / \mathrm{TL}(\mathrm{R}=0.675), \mathrm{CPL} / \mathrm{TL}(\mathrm{R}=0.381)$ and $\mathrm{CPD} / \mathrm{TL}(\mathrm{R}=0.563)$. This is meaning that ED and PreOL are increasing moderately with HL. Furthermore, all the fish fins DFL, PFL, VFL, AFL, CFL, CFH grow moderately with TL. Also the CPL and CPD of $P$. stridens are increasing moderately with TL. With regard to the previous studies, the linear relationship of some morphometric characters (head length, snout length, eye diameter and caudal peduncle) and total length was reported by Safi et al. (2014) for males and females specimens of $P$. stridens from Karachi Coast, Pakistan. They found that all the body parameters show high values of correlation with total length and head length.

Table (4): The relationship between different morphometric characters and total length \& head length of $P$. stridens from Gulf of Suez.

\begin{tabular}{|c|c|c|c|}
\hline & Character & $\begin{array}{l}\text { Regression Equation } \\
\quad " Y=b X+a "\end{array}$ & $\begin{array}{c}\text { Correlation Coefficient } \\
{ }^{6} \mathbf{R} "\end{array}$ \\
\hline$\underline{1}$ & FL/TL & $y=0.9175 x+0.2577$ & 0.984 \\
\hline$\underline{2}$ & SL/TL & $y=0.8396 x+0.2080$ & 0.973 \\
\hline$\underline{3}$ & HL/TL & $y=0.1969 x+0.2364$ & 0.838 \\
\hline 4 & HD/TL & $y=0.1689 x+0.0886$ & 0.805 \\
\hline$\overline{5}$ & BD/TL & $y=0.1721 x+0.3810$ & 0.736 \\
\hline$\underline{6}$ & ED/HL & $y=0.1401 x+0.1299$ & 0.506 \\
\hline$\overline{7}$ & PreOL/HL & $y=0.2411 x-0.0466$ & 0.653 \\
\hline$\underline{8}$ & PreDL/TL & $y=0.2446 x+0.1249$ & 0.757 \\
\hline$\overline{9}$ & DFL/TL & $y=0.2459 x+1.3221$ & 0.614 \\
\hline 10 & PrePL/TL & $y=0.2466 x-0.0360$ & 0.871 \\
\hline$\underline{11}$ & PFL/TL & $\mathrm{y}=0.1471 \mathrm{x}-0.2390$ & 0.642 \\
\hline$\underline{12}$ & PreVL/TL & $y=0.2416 x-0.1764$ & 0.869 \\
\hline$\overline{13}$ & VFL/TL & $y=0.0924 x+0.0249$ & 0.598 \\
\hline 14 & PreAL/TL & $\mathrm{y}=0.5224 \mathrm{x}-0.1341$ & 0.902 \\
\hline 15 & AFL/TL & $y=0.0156 x+0.5135$ & 0.387 \\
\hline$\overline{16}$ & CFL/TL & $y=0.0890 x+0.5870$ & 0.647 \\
\hline 17 & CFH/TL & $y=0.0475 x-0.0260$ & 0.675 \\
\hline$\underline{18}$ & CPL/TL & $y=0.0829 x+0.5269$ & 0.381 \\
\hline$\overline{19}$ & CPD/TL & $y=0.063 x-0.11150$ & 0.563 \\
\hline
\end{tabular}




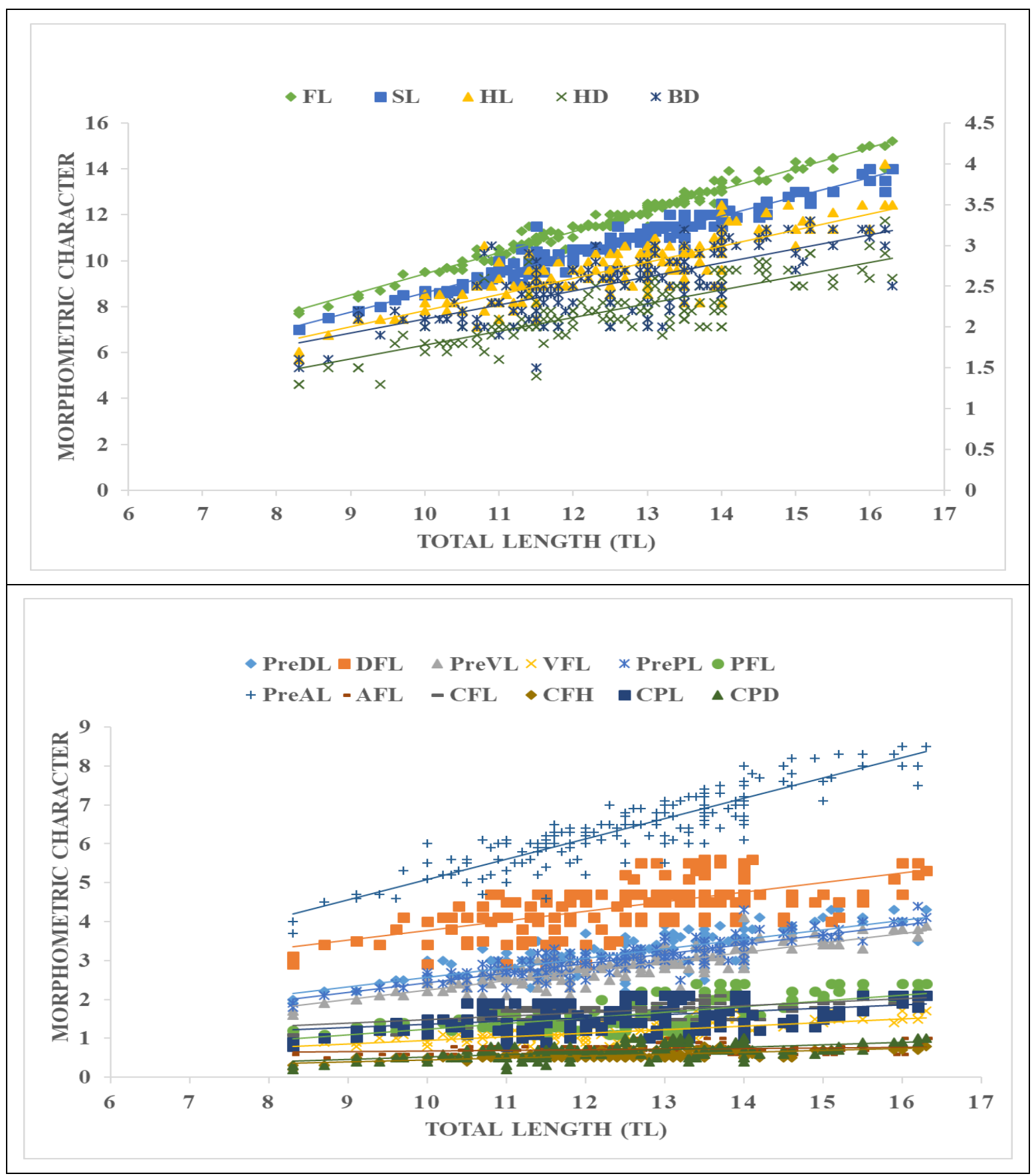

Fig. (4): The relationship between various morphometric characters and total length of $P$. stridens from Gulf of Suez.

\section{Meristics Characters:}

The meristic characters of Pomadasys stridens in the Gulf of Suez for the three length groups were given in Table (5). It was clear that there were no differences in meristic characters with the increase in body length, where all the meristic characters remained constant with increasing body length. It means that the meristic counts are independent of body size. The fin formula of P. stridens in the Gulf of Suez of the present 
investigation can be written as"D XII+14; A III+8; P 15; V I+5; C 15”; 12 spines and 14 soft rays in the dorsal fin; 3 spines and 8 soft rays in the anal fin; 15 soft rays in the pectoral fin; 1 spine and 5 soft rays in pelvic fin and 15 soft rays in the caudal fin. These finding were more or less accord with those of the previous studies. The fin formula $D$, XII + 13-14; A, III+7 were given by Smith and Mckay (1986) and Iwatsuki et al. (1995) for P. stridens. Bilecenoğlu et al. (2009) they documented that the fin elements counts were 12 spines and $14-15$ rays in dorsal fin; 3 spines and $8-9$ rays in anal fin, pectoral fin with $16-17$ rays. The fin formula D, XII+12; A, III+9 was reported by Safi et. al. (2014) for P. stridens from Karachi Coast-Pakistan. Iglesias and Frotte (2015) had recorded the fin formula for $P$. stridens in the Mediterranean Sea, Cyprus and gave the following formula D: XII+13; A: III+9; P: 17; V: I+5. The fin formula D: XII + 13; A: III + 8; P: 16; V: I + 5 were reported by Akyol and Ünal (2016) for P. stridens from the Aegean Sea, Turkey. Akyol and Çoker (2018) gave the fin formula D, XII+13; A, III+8; P, 17; V, I+5 for P. stridens, captured from Marmaris Bay, SE Aegean Sea, Turkey. Froese and Pauly (2020) had documented the fin formula of the $P$. stridens as follow $\mathrm{D}$, XII + 13-16; A, III + 8-9; P, 16-28; V, I + 5.

The number of lateral-line scales for $P$. stridens in the Gulf of Suez for the present study were recorded as the pored scales of the lateral line between the upper end of the gill opening and base of the caudal fin. It was found to be equal $57 \pm 0.13$. LLS number that recorded in the present study were nearly fall in the same range given by Fischer and Bianchi (1984) (LLS = 56 - 61); Bilecenoğlu et al. (2009) (52 - 60 pored scales in lateral line; 9 - 10 scales between lateral line and dorsal fin origin) for $P$. stridens from the Eastern Mediterranean Sea; Safi et al. (2014) (LLS = 57 - 60) for $P$. stridens from Karachi Coast-Pakistan, as well as Froese and Pauly (2020) (LLS = 57- 60) and less than that recorded by Iglesias and Frotte (2015) $(\mathrm{LLS}=59)$ for $P$. stridens in the Mediterranean Sea, Cyprus and exceed that given by Smith and Mckay (1986) and Iwatsuki et al. (1995) who give the number of pored lateral line scales 49 - 53 and 5 - 6 on scaly sheath of caudal fin for $P$. stridens.

Gill rakers were 7 on upper limb and 15 on lower limb of the first gill arch $(\mathrm{GR}=$ $22 \pm 0.09)$ for $P$. stridens in the Gulf of Suez of the present study. This count is higher than that reported by Safi et al. (2014) (GR = 15 - 16) for P. stridens from Karachi Coast, Pakistan and less than that registered by Iglesias and Frotte (2015) $(\mathrm{GR}=24)$ for $P$. stridens in the Mediterranean Sea, Cyprus. On the other hand GR value of $P$. stridens in the present study is similar to that recorded by Froese and Pauly (2020) (GR= 21 - 24). The recorded number of vertebrae of $P$. stridens in the Gulf of Suez through the present investigation were $24 \pm 0.11$. The number of vertebrae for $P$. stridens were not recorded in all the previous studies that investigate the meristic characteristics of $P$. stridens worldwide . 
Table (5): The meristic characters of $P$. stridens from the Gulf of Suez.

\begin{tabular}{l|l|c|c|c|c}
\hline \multicolumn{2}{l|}{ Character } & Length group (I) & Length group (II) & Length group (III) & Mean \\
(I, II, II) \\
\hline$\underline{\mathbf{1}}$ & DFS & $12 \pm 0.00$ & $12 \pm 0.00$ & $12 \pm 0.00$ & $12 \pm 0.00$ \\
\hline$\underline{\mathbf{3}}$ & DFR & $14 \pm 0.07$ & $14 \pm 0.07$ & $14 \pm 0.07$ & $14 \pm 0.04$ \\
\hline$\underline{\mathbf{4}}$ & AFR & $3 \pm 0.02$ & $3 \pm 0.00$ & $3 \pm 0.00$ & $3 \pm 0.01$ \\
\hline$\underline{\mathbf{5}}$ & PFR & $15 \pm 0.12$ & $8 \pm 0.07$ & $8 \pm 0.08$ & $8 \pm 0.04$ \\
\hline$\underline{\mathbf{6}}$ & VFS & $1 \pm 0.00$ & $15 \pm 0.15$ & $15 \pm 0.14$ & $15 \pm 0.08$ \\
\hline$\underline{\mathbf{z}}$ & VFR & $5 \pm 0.05$ & $1 \pm 0.00$ & $1 \pm 0.00$ & $1 \pm 0.00$ \\
\hline$\underline{\mathbf{8}}$ & CFR & $15 \pm 0.00$ & $5 \pm 0.02$ & $5 \pm 0.04$ & $5 \pm 0.01$ \\
\hline Fin Formula: & D XII+14; A III+8; P 15; V I+5; C 15 & $15 \pm 0.00$ & $15 \pm 0.00$ \\
\hline$\underline{\mathbf{9}}$ & LLS & $57 \pm 0.21$ & $57 \pm 0.24$ & $56 \pm 0.21$ & $57 \pm 0.13$ \\
\hline$\underline{\mathbf{1 0}}$ & GR & $22 \pm 0.09$ & $22 \pm 0.09$ & $22 \pm 0.09$ & $22 \pm 0.09$ \\
\hline$\underline{\mathbf{1 1}}$ & V & $24 \pm 0.11$ & $24 \pm 0.11$ & $24 \pm 0.11$ & $24 \pm 0.11$ \\
\hline
\end{tabular}

* Values are expressed as mean $\pm \mathrm{SE}$.

\section{CONCLUSION}

The present study gave a detailed description of morphological diagnosis, morphometrics and meristics of $P$. stridens needed for its identification and distinguish it from other similar fish species in the investigated area; Gulf of Suez, Red Sea, Egypt. All the morphometric characters are dependent on body size, while all the meristic are independent of body size. The positive linear relationship had been observed between FL, SL HL, HD, ED, PreOL BD, PreDL, DFL, PrePL, PFL, PreVL, VFL, PreAL, AFL, CFL, CFH, CPL, CPD and TL; also between ED, PreOL and HL. Out of twenty morphometric character, eight characters show high values of correlation coefficient and eleven characters show moderate correlation coefficient. Eleven meristic characters were counted and the fin formula were drawn for this fish species. The morphometric measurements and meristic counts confirmed that the population of $P$. stridens from Suez Gulf are quite similar to those in other places worldwide.

\section{REFERENCES}

Akyol O. and Ünal V. (2016): First record of a Lessepsian migrant, Pomadasys stridens (Actinopterygii: Perciformes: Haemulidae), from the Aegean Sea, Turkey. Acta Ichthyol. Piscat. 46 (1): 53-55.

Akyol, O. and Çoker, T. (2018): On the Presence of the Lessepsian Pomadasys stridens (Haemulidae) in the Aegean Sea (Marmaris Bay, Turkey). Turkish Journal of Maritime and Marine Sciences, 4 (2): 163-166. 
Al-Faisal, A. J. and Mutlak, F. M. (2018): Occurrence of two grunt fish (Haemulidae: Pomadasys) from the Iraqi marine waters, International Journal of Marine Science, 8 (21): 172-175.

Appa Rao, T. (1966): On some aspects of biology of Lactarius lactarius (Schn). Indian J. Fish., $13: 334-349$.

Bailly, N.; Reyes, R. B.; Atanacio, R. and Froese, R. (2010): Simple Identification Tools in FishBase. Tools for Identifying Biodiversity: Progress and Problems pp. 31-36. ISBN 978-88-8303-295-0. EUT. https://www.fishbase.se/summary/Pomadasys-stridens.html.

Bilecenoğlu, M.; Kaya, M. and Eryiğit, A. (2009): New data on the occurrence of two alien fishes, Pisodonophis semicinctus and Pomadasys stridens, from the Eastern Mediterranean Sea. Mediterranean Marine Science, 10 (2): 151-155.

Brraich, O. S. and Akhter, S. (2015): Morphometric characters and meristic counts of a fish, Crossocheilus latius latius (Hamilton-Buchanan) from Ranjit Sagar Wetland, India. International Journal of Fisheries and Aquatic Studies, 2 (5): 260265.

Burhanuddin, A. I. and Iwatsuki, Y. (2012): The grunts (Family: Haemulidae) of the Spermonde Archiopelago, South Sulawesi. Jurnal Ilmu dan Teknologi Kelautan Tropis, 4 (2): 229-238.

Dwivedi, S. N. and Menezes, M. R. (1974): A note on morphometry and ecology of Brachiunius orientalis (Bloch \& Schenider) in the estuary of Goa. Geobios, 1: 80 -83 .

El-Azim, H. A.; Mehanna, S. F. and Belal, A. A., (2017). Impacts of water quality, fishing mortality and food availability on the striped piggy Pomadasys stridens production in Bitter Lakes, Egypt. Annals of Marine Science, 1(1): 19-27.

El-Ganainy, A. A. and Sabrah, M. M. (2008): Population biology and assessment of the striped piggy Pomadasys stridens in the Bitter Lakes Suez Canal. Egypt. J. Aqua. Res. 34 (2): 372-382.

Fischer, W. and Bianchi, G. (eds.) (1984): Haemulidae. FAO species identification sheets for fishery purposes. Western Indian Ocean (Fishing area 51). Vol. 2:pag. var.

Fors[s]kål, P. (1775): Descriptiones animalium; avium, amphibiorum, piscium, insectorum, vermium, quae in itinere orientali observavit, Hauniae, $20+$ xxxiv +164 pp., 1 map.

Fricke, R.; Eschmeyer, W. N.; and Van der Laan, R. (eds). (2020): Eschemeyer's catalog of fishes: genera, species. http://researcharchive.calacademy.org/ research/ichthyology/catalog/fishcatmain.asp.

Froese R. and Pauly D. (eds). (2020): FishBase (version Feb 2018). In: Species 2000 \& ITIS Catalogue of Life, 2020-04-16 Beta (Roskov Y.; Ower G.; Orrell T.; Nicolson D.; Bailly N.; Kirk P.M.; Bourgoin T.; DeWalt R.E.; Decock W.; Nieukerken E. van; Penev L.; eds.). Digital resource at www.catalogueoflife.org/col. Species 2000: Naturalis, Leiden, the Netherlands. ISSN 2405-8858.

GAFRD (2018): General Authority for Fish Resources Development. Annual fishery statistics report, Cairo, Egypt. 116 pp.

Iglesias S. P. and Frotte L. (2015): Alien marine fishes in Cyprus: update and new records. Aquatic Invasions (2015) Volume 10, Issue 4: 425-438. 
Iwatsuki, Y., Yoshino, T.; Golani D. and Kanda, T. (1995): The validity of the haemulid fish Pomadasys quadrilineatus Shen and Lin, 1984 with the designation of the neotype of Pomadasys stridens (Forrskål, 1775). Jap. J. Ichthyol. 41 (4): 455-461.

Liang, R.; Zhuo, X.; Yang, G.; Luo, D.; Zhong, S. and Zou, J. (2012): Molecular phylogenetic relationships of family Haemulidae (Perciformes: Percoidei) and the related species based on mitochondrial and nuclear genes. The Journal of DNA Mapping, Sequencing, and Analysis., 23 (4): 264 - 277.

Nelson, J. S. (1994). Fishes of the world. Third edition. John Wiley \& Sons, Inc., New York. 600 p.

Osman, H. M.; Saber M. A. and El Ganainy, A. A. (2019): Population structure of the striped piggy Pomadasys stridens in the Gulf of Suez. Egyptian Journal of Aquatic Research, 45: 53-58.

Safi, A.; Atiqullah Khan, M. and Zaheer Khan, M. (2014): Study of some morphometric and meristic characters of striped piggy fish Pomadasys stridens (Forsskal, 1775) from Karachi Coast, Pakistan. The Journal of Zoology Studies, 1 (4): 01-06.

Sanciangco, M. D. (2014): Phylogeny and Biogeography of the Family Haemulidae based on a Multigene Approach. Doctor of Philosophy $(\mathrm{PhD})$, dissertation, Biological Sciences, Old Dominion University, 283 P.

Smith, M. M. and McKay, R. J. (1986). Haemulidae. p. 564-571. In M.M. Smith and P.C. Heemstra (eds.) Smiths' sea fishes. Springer-Verlag, Berlin.

Ukenyea, E. A.; Taiwob, I. A. and Anyanwuc, P. E. (2019): Morphological and genetic variation in Tilapia guineensis in West African coastal waters: A mini review. Biotechnology Reports, 24 (2019) e00362.

Yousif, A. (1990): Biological and fisheries studies on Pomadasys stridens in the Gulf of Suez M. Sc. Thesis. Fac. Sci. Suez Canal, Uni., Ismailia, Egypt.

Yousif, A. (2004): Abundance of the striped piggy (Pomadasys stridens) in the Northwest Red Sea, Egypt. Egypt. J. Aquat. Biol \& fish., 8 (3): 139-158. 